Role of Board- Manager Relation ...

\title{
Research Article \\ Role of Board- Manager Relation on Cooperative Performance
}

\author{
Dhaneshwar Rakhal \\ Faculty of Management, Prithvi Narayan Campus, Pokhara \\ Email: rakhald@hotmail.com
}

\begin{abstract}
Cooperatives are based on the philosophy of equality and mutual help i.e. 'All for each and each for all'. They cover a wide range of development services in Nepalese context. The members of a cooperative elect a board of directors in its general meeting for the day to day operation. The board prepares policy and procedures, and appoints manager(s) to implement the policies and run the program. One of the internal issues in saving and credit cooperatives is the relationship between managers and the board of directors which affects on the performance level of the cooperative. In this regard, the main objective of this paper is to assess the relationship between managers and the board of directors, and its impact on the performance of saving and credit cooperatives in Pokhara. The study also covers the managers' feelings of job satisfaction, career development opportunities, and responsibilities of board of directors and managers. Out of 212 savings and credit cooperatives in Pokhara Sub-metropolitan, 77 cooperatives were selected as sample. A questionnaire survey with the mangers was carried out to derive the primary information, and annual audited reports are used as secondary sources of data. The results indicate that board-manager relation does not affect the responsibilities of board of directors and managers, and academic qualifications of managers are positively related to performance of the cooperatives. Finally the paper concludes that the board manager relationship is positively related to return on assets of the cooperatives.
\end{abstract}


Janapriya Journal of Interdisciplinary Studies, Vol. 6 (December 2017)

Keywords: Board of directors, job satisfaction, managers, performance, Pokhara, returns on assets, saving and credit cooperatives

\section{Introduction}

Cooperative is a member controlled business which covers a wide range of development services. Cooperatives have been instrumental in financial inclusion for the rural and agricultural households in Nepal. It is accepted as a most important part of three-pillar economy comprising of the state, cooperatives and the private sector. Although, there are some serious issues in cooperatives, especially in saving and credit cooperatives such as the requirement for suitable legislation for regulating such cooperatives, effective supervisory and monitoring arrangement, adhering to member based business activities, setting good governance practice, putting internal control in place, following ethical practices in business, and bridling the temptation to make and distribute undue profit (Khatiwada, 2014).

The internal structure of the cooperatives in Nepal contains general assembly as apex organization, the executive board of directors as the operational agency, and the account and the supervision committee as the strong internal committee with the responsibility to perform the job of auditing by itself or hiring the auditors. The board of directors can organize different subject-wise subcommittees to help in its daily activities smoothly according to needs (Thakuri, 2010). The board of directors appoints the employees of the cooperative society according to the needs of the organization. Most of the cooperatives appoint one manager, and the supporting staff having the position of assistant manager, accountant, cashier/treasurer, marketing staffs, security guards etc. (Thakuri, 2010).

Directors in a cooperative hold a crucial position between members and the managers. Normally, the manager of the cooperative leads the office, with the responsibility of daily transactions. Similarly, the manager act as a bridge between the board of directors and employees. In few cooperatives, one member from the board of director is working as executive director or managing director of the cooperatives (Thakuri, 2010; Zivkovic, Hudson, 
Role of Board- Manager Relation ...

Johnson \& Park, 2015). There are several issues relating to the cooperative governance performance i.e. diverse backgrounds of directors, duties and responsibilities of the board of directors and managers, good relation between board of directors and managers, maximizing resources and minimizing cost of cooperatives, and accepting the diverse roles by the managers (Santiaguel, n. d.). One of the issues of cooperatives is the relationship between manager and the board of directors of the cooperatives.

Another issue or challenge of saving and credit cooperative management that the cooperative members are consumers, farmers, workers, fishers, informal economy operators - they are not necessarily professional in managing cooperatives. Smaller cooperatives may not be able to hire professional managers and must therefore rely on the skills of elected member, who may excel in their trade but have never seen a balance sheet. This is the reverse of the medal of "democratic management", which needs to be addressed through training, education, and appropriate advisory, and support services (Schwettmann, 2014). The effectiveness of management is one of the most important factors in determining the success or failure of any firms, whether it is cooperative or an investor oriented firm. Both the board of directors and the managers are involved in the cooperative management process and activities such as planning, organizing, staffing, directing, and controlling. The board needs to keep managers adequately informed about cooperative plans, policies, and strategies. For the success of the cooperatives, the board requires to fulfill the adequate employees in a cooperative, to train employees, to take step for job satisfactions and to spend the career of the employees in the organization. The working relationship between the board and the manager requires respect and the understanding of each other's responsibilities for the cooperative to be successful (Cobia, 1989 as cited in Zivkovic et al., 2015). Thus, the board manager relationship is the most important part of the cooperative performance. 
Janapriya Journal of Interdisciplinary Studies, Vol. 6 (December 2017)

\section{Conceptual Framework}

Feltus, Petit and Vernadat (2009) define responsibility as "having the obligation to ensure that something happens" (p. 2). Feltus et al. also highlight that being responsible needs one or many capacities, accountabilities and commitments. But at the opposite, one commitment and accountability always relate to one responsibility, whereas one capability may be attached to many responsibilities. Accountability is the state of being accountable for the achievement of the results of an activity. Capability describes the required qualities, skills or resources to perform an activity (Feltus et al., 2009). Commitment is the moral engagement of a person to achieve objective and perform the task in respect of an ethical code. In cooperative societies, it is the responsibility of the board of directors to ensure that the cooperative societies comply with the standard and policies that enhance good governance (Otieno \& Ombuna, 2015). It means managers and boards are accountable for their own action relating to themselves and others.

The relationship between boards and manager is viewed very differently within the contrasting theoretical perspectives. The agency and democratic perspectives stress the importance of the board monitoring and controlling the work of managers. In contrast, stewardship theory stresses the role of the board as a partner to management, working in collaboration to improve top management decision-making (Cornforth, 2004). Mole (as cited in Cornforth, 2004) has pointed tension and conflict seems most likely to occur when boards and senior managers have different expectations of their respective roles. The interdependent of board and managers offer to establish a productive working relationship is through open discussion and negotiation over roles and responsibilities. Therefore, it is important that the boards regularly review their relationship with managers and how they are working together.

Job satisfaction refers to the attitudes and feelings of employees that they have about their work. Positive and favorable attitudes towards the job indicate job satisfaction. Therefore, job satisfaction is a positive emotional 
Role of Board- Manager Relation ...

state that employee experiences about their duties (Shrestha, 2015). Luthan (as cited in Tella, Ayeni \& Popoola, 2007) notes response, expectancy, and attitudes as dimensions of job satisfaction. Emotional response is the matter of experience and feeling. It cannot be seen or touched. Job satisfaction is also determined by how well outcomes meet the expectations of employee. So, it is the difference between the amount of rewards employees receive and the amount they expect they should receive. An attitude can be as a positive or negative evaluation of people, objects, events, activities, and ideas. Job satisfaction represents employees' attitudes about different factors: pay (salaries and wages), the work itself, career development opportunities, supervision and coworkers.

Manager with a high level of job satisfaction holds positive feelings about the job, while a person with a low level holds negative feelings. Job satisfaction influences on productivity and absenteeism of employees. Productivity has the efficiency relationship between input and output. The evidence suggests that productivity is likely to lead to satisfaction. It also seems that organizations with more satisfied workers as a whole are more productive organizations. Absenteeism is the failure of people to attend work. There is an inverse relationship between satisfaction and absenteeism. Consequently, managers' job satisfaction tends to center on its effect on organizational performance.

Performance is the act of carrying into action, achievement, accomplishment, representation, and duty. Performance management is the process of creating a work environment or setting in which people are enabled to perform to the best of their abilities (Otieno \& Ombuna, 2015). Performance management is a whole work system that begins when a job is defined as needed and it ends when an employee leaves the organization. Managing performance requires developing people with ensuring that organizational aims are achieved (Otieno \& Ombuna, 2015). It means, therefore, to look first at managing performance at the level of basic standards and responsibilities. 
Janapriya Journal of Interdisciplinary Studies, Vol. 6 (December 2017)

There is no consensus on the dimensions of organizational performance. Some studies focuses on one or two dimensions. However, two clear-cut dimensions can be suggested: financial and non-financial performance. The dimensions for financial performance include profitability, return on assets, return on investment, market return, sales revenue and others, while the dimensions for non-financial performance include customer satisfaction, job satisfaction, turnover, service quality, quality of job performance and others (Ilhaamie, 2015). Thus, organizational performance is a multidimensional concept. Hence, Seldon and Sowa (as cited in Ilhaamie, 2015) suggested that researchers use a multi-indicator in order to measure the complexity of the organizational performance dimension. In this regard, the study used only financial measure of performance i.e. ROA.

\section{Data and Methods}

The paper is descriptive in nature and mainly based participants' experiences and views. Primary data were obtained by using structured questionnaire survey. Annual audited reports of Finance Year 2015/16 are also collected from the sample cooperatives which are basically used for calculation of return on assets. Besides, literature related to cooperatives, manager and board relation, organizational/cooperatives performance are also consulted and used whenever necessary.

Mid July 2015, there were 212 savings and credit cooperatives in Pokhara Sub- metropolitan (Cooperative Training and Division Office, 2015). These entire cooperatives are treated as population. Out of 212 cooperatives, 77 cooperatives of Pokhara Sub-metropolitan were the sample of the study. The entire managers (i.e. office head) of the sample cooperatives are the sample respondents for the primary data and convenient sampling was used. Copies of questionnaire schedule with the cover letter were prepared as the instruments for the collection data. The questionnaire was based on previous research (Adrian \& Green, 2001; Zivkovic et al., 2015) and it was translated in Nepali to make it easier for the respondents. The respondents were visited for questionnaire survey in their offices of the cooperatives. The time for the respondents was set with the respondents' cooperation. The questionnaire was filled up and collected immediately. With the 
Role of Board- Manager Relation ...

questionnaire, the annual audited reports also collected from the sample cooperatives. All the data collected from the questionnaire and annual audited reports are processed in the computer using SPSS software. The responses frequencies are categorized and frequencies percentage are computed and interpreted. Additionally, regression analysis and regression models are used whether applicable.

The empirical model also used in the analysis is specified in following regression equation:

$R O A=\beta_{0}+\beta_{1}(J O B)+\beta_{2}(C A R E E R)+\beta_{3}(B O A R D)+\beta_{4}(A C A D E M)+$ $\beta_{5}(\operatorname{SEX})+\varepsilon$

In the model, return on assets $(R O A)$ represents dependent variable which is the performance variables of the cooperatives. The financial ratio, i.e. $R O A$ of all the sample cooperatives were calculated from their audited annual financial statements of the fiscal year 2071/72 (BS). In addition to the variable described above, other right side or independent variables include the overall job satisfaction $(J O B)$, career development opportunities (CAREER), board manager relationship (BOARD), academic qualification $(A C A D E M)$ and sex $(S E X)$ of the respondents. Similarly, intercept or a constant value $\left(\beta_{0}\right)$, regression coefficients $\left(\beta_{1}, \beta_{2} \ldots \beta_{5}\right)$ and error term $(\varepsilon)$ are also used on the right side of the regression equation.

\section{Results and Discussion}

\section{Background Information}

The responses regarding background information are presented in Table 1 to 4. Age distribution of the respondent managers is given in Table 1 . About 36.4 percent of managers are less than 30 years of age, 29.9 percent of managers are of 30 to 40 years of age, 20.8 percent are 40 to 50 years and the rest are more than 40 year and above. The average age of manager is 35.65 years. 
Janapriya Journal of Interdisciplinary Studies, Vol. 6 (December 2017)

Table 1

Age wise Classification of Respondents

\begin{tabular}{lrrrrr}
\hline Years & No & Percent & Mean & Minimum & Maximum \\
\hline $20-30$ & 28 & 36.4 & 35.65 & 22 & 63 \\
$30-40$ & 23 & 29.9 & Years & Years & Years \\
$40-50$ & 16 & 20.8 & & & \\
$50-60$ & 6 & 7.8 & & & \\
60 and Above & 4 & 5.2 & & & \\
Total & 77 & 100.0 & & &
\end{tabular}

Source: Survey Data 2016

As is evident from Table 2, majority of respondent (77.9 percent) are male and 22.1 percent are female respondents.

Table 2

Sex wise Classification of Respondents

\begin{tabular}{lrr}
\hline Sex & Number & Percent \\
\hline Male & 60 & 77.9 \\
Female & 17 & 22.1 \\
Total & 77 & 100.0 \\
\hline
\end{tabular}

Source: Survey Data 2016

As evident from Table 3, 76.6 percent of cooperative managers are married and the rest, 33.4 percent are unmarried. It indicates the dominance of married managers in saving and credit cooperatives in Pokhara.

Table 3

Marital Status of Managers

\begin{tabular}{lcr}
\hline Marital Status & No & Percent \\
\hline Married & 59 & 76.6 \\
Unmarried & 18 & 23.4 \\
Total & 77 & 100.0 \\
\hline
\end{tabular}

Source: Survey Data 2016 
Role of Board- Manager Relation ...

Table 4 shows the educational background of the managers of saving and credit cooperatives selected as sample. Most of the financial practitioners hold the bachelor or higher degree. The Table shows 48.1 percent of managers are holding bachelor's degree, 28.6 percent and 18.2 percent are holding master's degree and higher secondary degree respectively.

Table 4

Academic Qualification of Managers

\begin{tabular}{lrrrrrr}
\cline { 1 - 3 } Level-wise Qualification & & & & \multicolumn{2}{c}{ Stem-wise Qualification } \\
\cline { 1 - 2 } \cline { 5 - 7 } & No & Percent & & Stem & No & Percent \\
\hline Below Secondary Level & 1 & 1.3 & & Management & 52 & 67.5 \\
Secondary Level & 3 & 3.9 & & Law & 2 & 2.6 \\
Higher Secondary Level & 14 & 18.2 & & Social Science & 14 & 18.2 \\
Bachelor Level & 37 & 48.1 & & Education & 3 & 3.9 \\
Master and Above Level & 22 & 28.6 & & Other & 6 & 7.8 \\
Total & 77 & 100.0 & & Total & 77 & 100.0 \\
\hline
\end{tabular}

Source: Survey Data 2016

Similarly, 3.9 percent and 1.3 percent are holding secondary level and below secondary level respectively (Table 4). As was expected, the table also indicates most (67.5 percent) of the managers hold the degree in management stream (subject), 18.2 percent holds the degree in social sciences and 3.9 percent managers hold the degree in education stem. Rest other (7.8 percent) includes the degree in English literature, science, and without specialization (secondary and below the secondary level of education).

\section{Career Development Activities}

With respect to career development activities, the opportunities for the career development, managers' participation in cooperative management training, and their involvement in planning and budget preparation meeting were examined as variables of career development activities. About career development opportunities in the field of cooperatives, 37.7 percent respondents have felt satisfied, 26 percent stated not satisfied, 22.1 percent respondents have opinioned that they are dissatisfied, 9.1 percent 
Janapriya Journal of Interdisciplinary Studies, Vol. 6 (December 2017)

respondents have felt highly satisfied and 5.2 felt they are completely dissatisfied. Thus, the majority of the respondents are of opinion that they are dissatisfied in the on the career development in the job of cooperatives (Table 5).

Table 5

Career Development Opportunities

\begin{tabular}{lrr}
\hline Level of Satisfaction & No & Percent \\
\hline Highly satisfied & 7 & 9.1 \\
Satisfied & 29 & 37.7 \\
Not satisfied & 20 & 26.0 \\
Dissatisfied & 17 & 22.1 \\
Completely dissatisfied & 4 & 5.2 \\
Total & 77 & 100.0 \\
\hline
\end{tabular}

Source: Survey Data 2016

\section{Board Manager Relation}

As regards to the board manager relationship, managers were asked about the types of board manager relationship in their cooperatives.

Table 6

Board Manager Relation in Respondents' Cooperatives

\begin{tabular}{lrr}
\hline Relation & Frequency & Percent \\
\hline Parent-Child & 12 & 15.6 \\
Principal-Agent & 8 & 10.4 \\
Adult-Adult & 48 & 62.3 \\
Other & 9 & 11.7 \\
Total & 77 & 100.0 \\
\hline
\end{tabular}

Source: Survey Data 2016

In this regards, majority (62.3 percent) managers noted that their relationship is "adult-adult". Similarly, 15.6 percent, 11.7 percent, 10.4 percent managers noted that the relation: "parent-child", "other" and 
Role of Board- Manager Relation ...

"principal-agent" respectively (Table 6). The responses 'other' includes "neighbor", "leader follower", "friendship", "brotherhood", "chain of command", "body and mind" and "nail and marrow" (nang ra masu).

\section{Board Manager Responsibilities}

Managers were asked to rank eight areas of primary responsibility for performing by board or manager or equally between them (Table 7). For three of the eight areas, the majority of manager ranked "manager more responsible" or "manager most responsible". These areas are "managing day to day operations of the cooperatives" (94.8\%), "informing members about the cooperative and its activities" (61.1\%) and "furnishing information needed for long range planning" (48.1\%). Similarly, managers identified three areas where "board and manager equally responsible". These areas are: "informing members about the cooperative and its activities principles" (57.1\%), "developing programs for implementation of cooperative's policies" (53.2\%) and "setting of business for the welfare of the cooperative members" (42.8\%). Finally, manager selected only two areas where "board more responsible or board most responsible", are: "approving the purchase of major capital assets (72.8\%) and "maintaining minutes of the board of directors' meeting" (45.5\%). Out of eight areas, the result of six areas agrees with the result of Adrian and Green (2001). These six areas are: "managing day to day operations of the cooperatives", "furnishing information needed for long range planning", "informing member about the cooperatives and its activities", "developing programs for implementation of cooperative's policies", "setting of business for the welfare of the cooperative members" and "approving purchase of major capital assets" 
Janapriya Journal of Interdisciplinary Studies, Vol. 6 (December 2017)

Table 7

Managers' Responses for Division of Primary Responsibilities between Management and Board of Directors

\begin{tabular}{|c|c|c|c|c|c|c|}
\hline \multirow{2}{*}{ Area of Responsibility ${ }^{1}$} & \multirow{2}{*}{$\mathbf{N}$} & \multicolumn{5}{|c|}{ Response Ranking } \\
\hline & & 1 & 2 & 3 & 4 & 5 \\
\hline $\begin{array}{l}\text { a. Setting of business for the } \\
\text { welfare of the co-op members }\end{array}$ & 77 & $\begin{array}{c}18 \\
(23.4)^{2}\end{array}$ & $\begin{array}{c}13 \\
(16.9)\end{array}$ & $\begin{array}{c}33 \\
(42.8)\end{array}$ & $\begin{array}{c}5 \\
(6.5)\end{array}$ & $\begin{array}{c}8 \\
(10.4)\end{array}$ \\
\hline $\begin{array}{l}\text { b. Managing day to day operations } \\
\text { of the cooperatives }\end{array}$ & 77 & $\begin{array}{c}1 \\
(1.3)\end{array}$ & $\begin{array}{c}0 \\
(0)\end{array}$ & $\begin{array}{c}3 \\
(3.9)\end{array}$ & $\begin{array}{c}43 \\
(55.8)\end{array}$ & $\begin{array}{c}30 \\
(39.0)\end{array}$ \\
\hline $\begin{array}{l}\text { c. Maintaining minutes of the } \\
\text { board of directors' meeting }\end{array}$ & 77 & $\begin{array}{c}17 \\
(22.1)\end{array}$ & $\begin{array}{c}18 \\
(23.4)\end{array}$ & $\begin{array}{c}15 \\
(19.4)\end{array}$ & $\begin{array}{c}19 \\
(24.7)\end{array}$ & $\begin{array}{c}8 \\
(10.4)\end{array}$ \\
\hline $\begin{array}{l}\text { d. Approving purchase of major } \\
\text { capital assets }\end{array}$ & 77 & $\begin{array}{c}37 \\
(48.1)\end{array}$ & $\begin{array}{c}19 \\
(24.7)\end{array}$ & $\begin{array}{c}18 \\
(23.3)\end{array}$ & $\begin{array}{c}1 \\
(1.3)\end{array}$ & $\begin{array}{c}2 \\
(2.6)\end{array}$ \\
\hline $\begin{array}{l}\text { e. Developing programs for } \\
\text { implementation of co-op's policies }\end{array}$ & 77 & $\begin{array}{c}8 \\
(10.4)\end{array}$ & $\begin{array}{c}10 \\
(13.0)\end{array}$ & $\begin{array}{c}41 \\
(53.2)\end{array}$ & $\begin{array}{c}9 \\
(11.7)\end{array}$ & $\begin{array}{c}9 \\
(11.7)\end{array}$ \\
\hline $\begin{array}{l}\text { f. Furnishing information needed } \\
\text { for long range planning }\end{array}$ & 77 & $\begin{array}{c}6 \\
(7.8)\end{array}$ & $\begin{array}{c}6 \\
(7.8)\end{array}$ & $\begin{array}{c}28 \\
(36.3)\end{array}$ & $\begin{array}{c}27 \\
(35.1)\end{array}$ & $\begin{array}{c}10 \\
(13.0)\end{array}$ \\
\hline $\begin{array}{l}\text { g. Informing members about the } \\
\text { co-op and its activities principles }\end{array}$ & 77 & $\begin{array}{c}4 \\
(5.2)\end{array}$ & $\begin{array}{c}3 \\
(3.9)\end{array}$ & $\begin{array}{c}23 \\
(29.8)\end{array}$ & $\begin{array}{c}31 \\
(40.3)\end{array}$ & $\begin{array}{c}16 \\
(20.8)\end{array}$ \\
\hline $\begin{array}{l}\text { h. Hiring, training and setting } \\
\text { compensation for employees }\end{array}$ & 77 & $\begin{array}{c}15 \\
(19.5)\end{array}$ & $\begin{array}{c}15 \\
(19.5)\end{array}$ & $\begin{array}{c}44 \\
(57.1)\end{array}$ & $\begin{array}{c}1 \\
(1.3)\end{array}$ & $\begin{array}{c}3 \\
(2.6)\end{array}$ \\
\hline
\end{tabular}

Note. The divisions of response are defined as follows: $1=$ board most responsible, $2=$ board more responsible, $3=$ Board and manager equally responsible, $4=$ manager more responsible and $5=$ manager most responsible.

Source: Survey Data 2016

\footnotetext{
${ }^{1}$ Adrian and Green (2001) used fourteen areas of responsibility relating to board and manager of the cooperatives. Out of them only eight areas are appropriate in Nepalese context and used in this paper.

${ }^{2}$ Figures in parentheses indicate percentage over total responses.
} 
Role of Board- Manager Relation ...

For the calculation of the overall board manager responsibilities, all the variables of areas of responsibilities, setting of business for the welfare of the co-op members, managing day to day operations of the cooperatives, maintaining minutes of the board of directors' meeting, approving purchase of major capital assets, developing programs for implementation of cooperative's policies, furnishing information needed for long range planning, informing members about the co-op and its activities, principles and Hiring, training and setting compensation for employees, have been added to get overall job satisfaction level of the managers. Then the median was computed to find the percent of responsibilities of board, manager and both. Median value has been used to find out overall board manager responsibilities because of responsibilities is being the qualitative dimension. The final outcome shows 48.1 percent, 45.5 percent and 6.5 percent of the board of directors, managers and both (combining board of directors and managers) are responsible for the given areas (Table 8).

\section{Table 8}

Overall Responsibilities between Management and Board of Directors

\begin{tabular}{lrr}
\hline Particulars & No & Percent \\
\hline Board of Directors & 35 & 45.5 \\
Both (Board of Directors and Managers) & 5 & 6.5 \\
Managers & 37 & 48.1 \\
Total & 77 & 100.0 \\
\hline
\end{tabular}

Source: Survey Data 2016

To test whether the association between board manager responsibility and board manager relationship is significant, chi-square test was run, but there is no significant association observed. The result indicates that board manager responsibility and board manager relation are not related (since the p-value .368 is greater than 5 percent). It means board manager relationship does not affect the responsibilities of the board of directors and managers (Chi square $=6.5$ with df 6 and $p$-value $=0.368$ ). 
Janapriya Journal of Interdisciplinary Studies, Vol. 6 (December 2017)

\section{Job Satisfaction}

All the job satisfaction variables, job security, reward and punishment system, compensation and benefit system, communication with the board, nature of the work, current remuneration system, career development opportunities, nature of supervision and business relation with the board, have been added to get overall job satisfaction level of the managers. The final outcome shows 44.2 percent of managers are satisfied and 55.8 percent of managers are dissatisfied (Table 9).

Table 9

Overall Job Satisfaction

\begin{tabular}{lcr}
\hline Response & No & Percent \\
\hline Satisfied & 34 & 44.2 \\
Dissatisfied & 43 & 55.8 \\
Total & 77 & 100.0 \\
\hline
\end{tabular}

Source: Survey Data 2016

\section{Organizational Performance and Board Manager Relation}

One model is developed to evaluate the impact of overall job satisfaction, career development opportunities, academic qualification, sex of the respondents and board manager relation on the financial performance of saving and credit cooperatives in which financial performance is measured by return on assets.

For the purpose of the linear regression of ROA on the various measures (independent variables) produces the following results:

$R O A=4.67-0.282(J O B)+0.004(C A R E E R)+0.226(B O A R D)+$ $0.792(A C A D E M)-1.461(S E X)$

The ANOVA points out that the overall fit of the model is significant because $\mathrm{p}$-value is less than one percent ( $\mathrm{p}$-value $=0.001$ with df 5 and Fvalue $=4.45$ ). The model indicates that academic qualification and board 
Role of Board- Manager Relation ...

manager relationship are positively related to ROA (but not significant because p-value of both 0.115 and 0.613 are greater than five percent level). In the model, the overall job satisfaction is negatively related with ROA where as p-value (0.002 is less than one percent) is highly significant (Table 10). This is conflicting results as compared to earlier studies (Zivkovic et al., 2015) which may be due to the various limitations such as information on ROA, computation of overall job satisfaction etc.

Table 10

Regression Equation of ROA on Selected Variables

\begin{tabular}{|c|c|c|c|c|c|}
\hline \multirow[b]{2}{*}{ Model } & \multicolumn{2}{|c|}{$\begin{array}{l}\text { Unstandardized } \\
\text { Coefficients }\end{array}$} & $\begin{array}{c}\text { Standardized } \\
\text { Coefficients } \\
\end{array}$ & \multirow[b]{2}{*}{$\mathbf{t}$} & \multirow[b]{2}{*}{ Sig. } \\
\hline & B & Std. Error & Beta & & \\
\hline (Constant) & 4.671 & 3.315 & & 1.409 & .163 \\
\hline Overall Job Satisfaction & -.282 & .088 & -.380 & -3.191 & .002 \\
\hline $\begin{array}{l}\text { Career development } \\
\text { opportunities }\end{array}$ & .004 & .406 & .001 & .010 & .992 \\
\hline Board Manager Relation & .226 & .446 & .055 & .508 & .613 \\
\hline Academic Qualification & .792 & .497 & .193 & 1.595 & .115 \\
\hline Sex of Respondents & -1.461 & 1.002 & -.171 & -1.458 & .149 \\
\hline
\end{tabular}

Dependent Variable: ROA

Source: Survey Data 2016

\section{Conclusion}

With the purpose of assessing the effect of Board-Manager relation on the performance level of cooperatives in Nepalese context based on a questionnaire survey in Pokhra, this study finds that this relation is more 'adult- adult' relation. The majority of the managers are well-qualified, energetic, matured and competent in their field however; the percentage of female managers is low. Regarding career development opportunities, the majority of the sample respondents expressed their dissatisfaction. Similarly, under the heading of Board-Manager responsibilities, the data shows that the Board is more responsible than the managers and the combination of both. However, the result of chi-square indicates that the 
Janapriya Journal of Interdisciplinary Studies, Vol. 6 (December 2017)

Board-manager relation does not affect the responsibilities of the board of directors and managers.

Concerning the cooperative performance and board manager relation, one model is developed to evaluate the impact of overall job satisfaction, career development opportunities, academic qualification, sex of the respondents and board manager relation on the financial performance of saving and credit cooperatives in which financial performance is measured by return on assets. The model indicates that academic qualification and board manager relationship is positively related but not significant. In the model, the overall job satisfaction is negatively related with return on assets where as p-value is highly significant.

\section{Acknowledgement}

This article is the outcome of a mini research report submitted to the Center for Research, Rector's Office, Tribhuvan University, Kirtipur. I would like to acknowledge Professor Dr. Tara Datta Bhatta, Executive Director, Rector's Office, Tribhuvan University, for his valuable advice in course of the research conduction. I am equally thankful to Professor Dr. Vikash Kumar KC, Department of Statistics, Prithvi Narayan Campus, Pokhara, Mr Ramesh Dhakal, Under Secretary, Ministry Federal Affair and Local Development, Government of Nepal, and Radha Devi Sharma, Lecturer, Department of English, Prithvi Narayan Campus for their constant inspiration and help during the preparation of this paper. I am also grateful to those patient managers/office head of sample cooperatives of Pokhara, for providing necessary information and literature for this work.

\section{References}

Adrian, J. L., \& Green, T. W. (2001). Agricultural cooperative managers and the business environment. Journal of Agribusiness, 19(1), 1733 .

Cooperative Training and Division Office. (2015). Cooperatives in Kaski: An outlook. Pokhara: Author. 
Role of Board- Manager Relation ...

Cornforth, C. (2004). The governance of cooperatives and mutual associations: A paradox perspective. Annals of Public and Cooperative Economics, 75(1), 11-32.

Feltus, C., Petit, M., \& Vernadat, F. (2009). Refining the notion of responsibility in enterprise engineering to support corporate governance of IT. IFAC Proceedings Volumes, 42(4), 924-929.

Ilhaamie, A. G. A. (2015). Islamic human resource practices and organizational performance: some findings in a developing country. Journal of Islamic Accounting and Business Research, 6(1), 2-18.

Khatiwada, Y. R. (2014, March). Cooperatives, economic democracy and human security: perspectives from Nepal. Paper presented at 1st National Cooperative Congress, Kathmandu, Nepal.

Otieno, S., \& Ombuna, E. H. (2015). Effect of corporate governance practices on performance of coffee cooperative societies in Kisii Central Kisii County Kenya. International Journal of Research, 2(3), 138-158.

Schwettmann, J. (2014, December). The role of cooperatives in achieving the sustainable development goals: The economic dimension. Paper presented in the program on The Role of Cooperatives in Sustainable Development for All: Contributions, Challenges and Strategies, Nairobi, Kenya.

Shrestha, P. (2015). Organizational behavior. Kathmandu: Samjhana Publication.

Santiaguel, E. M. (n. d.). Governance issues in cooperatives. From http://gwhs-stg01.i.gov.ph/ s1cdagovph/images/Downloads/OtherInformation/LSC_Cluster_Congress/07-Governance-Issues.pdf

Tella, A., Ayeni, C. O., \& Popoola, S. O. (2007). Work motivation, job satisfaction, and organisational commitment of library personnel in academic and research libraries in Oyo State, Nigeria. Library philosophy and practice, 9(2), 1-13.

Thakuri, C. B. (2010). An anatomy of cooperative movement in Nepal. Kathmandu: Upkar Prakashan. 
Janapriya Journal of Interdisciplinary Studies, Vol. 6 (December 2017)

Zivkovic, S., Hudson, D., Johnson, P., \& Park, J. (2015, February). Impact of the relationship between managers and board of directors on performance of agricultural cooperatives. Paper presented at the Southern Agricultural Economics Association (SAEA) Annual Meeting, Atlanta, Georgia. 